The Christian Revolutionary 



\section{The Christian Revolutionary: John Milton}

\section{HUGH M. RICHMOND}

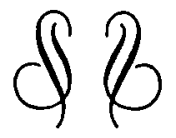

University of California Press

Berkeley, Los Angeles, London 
University of California Press

Berkeley and Los Angeles, California

University of California Press, Ltd.

London, England

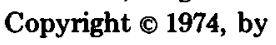

The Regents of the University of California

ISBN: 0-520-02443-5

Library of Congress Catalog Card Number: 73-76107

Printed in the United States of America 
To Phil and Jane Brady,

for many merry meetings

in Cambridge and elsewhere 
